\title{
Особливості якісних та кількісних показників крові в осіб із захворюванням серцево-судинної системи
}

\section{Тетяна Качинська, Тетяна Лисюк, Наталія Лавренюк, Анна Тимощук, Валентина Вовк, Ігор Коцан}

Волинський національний університет імені Лесі Украӥнки, Луцьк, Украӥна

Адреса для листування: Kachynska.Tatiana@vnu.edu.ua

Отримано: 03.12.21; прийнято до друку: 24.12.21; опубліковано: 30.12.21

Резюме. Мета дослідження полягала у вивченні якісних та кількісних показників системи крові в осіб із діагнозом ішемічна хвороба серця та інфаркт міокарда. Вибірка досліджуваних склала 40 осіб жіночої статі, віком 36-60 років, які проживали на території Волинської області. Всі досліджувані були поділені на 2 групи: I - жінки з діагнозом ішемічна хвороба серця (20 осіб); II - жінки 3 діагнозом інфаркт міокарда (20 осіб). Згідно з результатами аналізували клінічні показники крові.

Було виявлено, що в жінок зрілого віку, які мають порушення в роботі серця, найбільш чутливими до дії захворювання були показники крові: кількість еритроцитів, тромбоцитів, гемоглобіну, значення гематокриту та швидкості осідання еритроцитів, індекс розправлення еритроцита, а серед параметрів лейкоцитарної формули - нейтрофіли. Досліджувані із хворобою інфаркт міокарда мали гірші стосовно «норми» значення порівняно з пацієнтками з діагнозом IXC.

Ключові слова: інфаркт міокарда, ішемічна хвороба серця, кров.

\section{Features of qualitative and quantitative indicators of blood in persons with cardiovascular disease}

\section{Tetiana Kachynska, Tetiana Lysyuk, Natalia Lavrenuk, Anna Timoshchuk, Valentina Vovk, Ihor Kotsan}

Lesia Ukrainka Volyn National University, Lutsk, Ukraine

Correspondence: Kachynska.Tatiana@vnu.edu.ua

Abstract. The purpose of the study was to identify the qualitative and quantitative indicators of the blood system in people diagnosed with coronary heart disease and myocardial infarction. The sample consisted of 40 females, aged 36-60 years, who lived in the Volyn region. All subjects were divided into 2 groups: I - subjects diagnosed with coronary heart disease ( 20 females); II - subjects with a diagnosis of myocardial infarction (20 females). According to the results, clinical blood parameters were analyzed.

It was shown that in adult women with cardiac disorders the most sensitive to the disease were blood counts: erythrocytes, platelets, hemoglobin, hematocrit and erythrocyte sedimentation rate, erythrocyte straightening index, and among the parameters of the leukocyte formula - neutrophils. Subjects with myocardial infarction are characterized by worse values in relation to the «normal» compared to patients diagnosed with coronary heart disease.

Key words: myocardial infarction, coronary heart disease, blood.

\section{ВСТУП}

Однією з найважливіших медико-біологічних і соціальних проблем в Україні та й загалом у світі $є$ поширення серед населення серцево-судинних захворювань. Причинами їх виникнення та поширення $\epsilon$ недотримання здорового способу життя та постаріння населення. Регіональні відмінності захворюваності та поширення серцево-судинних хвороб насамперед визначаються віковою структурою населення, тривалістю життя, поширенням соціальних негараздів, способом та якістю життя [1].

У структурі захворюваності населення у 2015 році на серцево-судинні хвороби припадало понад $30 \%$ від усіх захворювань, зокрема серед працездатного населення - $24 \%$, осіб пенсійного віку - 50 \%. Захворюваність населення України на серцево-судинні хвороби у 2015 році складала 4,3 тис. хворих на 100 тис. осіб [2]. 
Ішемічна хвороба серця (IXC) становить основну причину захворюваності та смертності серед дорослого населення як у світі, так і в Україні. Проблема діагностики IXC знаходиться в полі діяльності сімейних лікарів, терапевтів та кардіологів. Проте часто перший контакт пацієнта з IXC відбувається 3 представниками екстреної медичної допомоги (ЕМД): лікарями, фельдшерами, медичними сестрами. Диференційна діагностика больового синдрому часто потребує глибоких знань щодо механізмів виникнення болю. Адже найважливіше діагностувати гострий коронарний синдром (ГКС): інфаркт міокарда, нестабільну стенокардію, що потребує ранньої інвазивної тактики лікування. Саме на ранній реперфузійній терапії ГКС базуються сучасні світові, європейські та локальні протоколи надання допомоги пацієнтам [3, 4]. Проблема старіння населення в Україні, як і в більшості країн Західної Європи, викликає потребу у більш доскональному вивченні морфологічних, патофізіологічних і клінічних особливостей гострого інфаркту міокарда в пацієнтів похилого віку [5].

У зв'язку з високим рівнем захворюваності і смертності від серцево-судинної патології, де безумовним лідером є IXC, вивчення механізмів розвитку коронарної недостатності $є$ актуальною проблемою [6]. Відомо, що ускладнення IXC, зокрема тромбози коронарних артерій та епізоди ішемії міокарда, мають закономірну добову структуру [10]. Згідно 3 даними, репрезентованими ВОО3 у 2004 році, смертність жінок європейської популяції від СС3 складає $55 \%$, тоді як чоловіків - лише $43 \%$ [5]. До 45 років у жінок порівняно з чоловіками того ж віку частота IXC в 4-6 разів нижча, а за наявності IXC ризик розвитку інфаркту міокарда (IM) нижчий у 2 рази. Значно нижчий і ризик раптової смерті аритмічного генезу [7]. Після 45-50 років у жінок підвищується не лише частота розвитку АГ, а й ризик виникнення IXC та сумарний серцево-судинний ризик [8].

Перебіг інфаркту міокарда у хворих характеризується особливостями, пов'язаними 3 поширеністю атеросклеротичного процесу, наявністю серцевої недостатності і супутньої патології. Часто ішемія міокарда в цих пацієнтів має безбольовий характер. Новітні прилади для дослідження крові видають десятки параметричних даних про ії стан, що дозволяє майже завжди безпомилково визначити діагноз хворого і навіть передбачити зміни деяких параметрів у будь-якої людини [9]. Тому важливим $\epsilon$ зіставлення клінічних, біохімічних, інструментальних даних, лабораторних показників. Це дозволить спрогнозувати перебіг, визначитися 3 індивідуальною тактикою ведення хворих, а також розробити рекомендації із вторинної профілактики IM [10]. А отже, мета дослідження - виявити особливості якісних та кількісних показників системи крові в осіб із діагнозом ішемічна хвороба серця та інфаркт міокарда.

\section{КОНТИНГЕНТ І МЕТОДИ ДОСЛІДЖЕНЬ}

Дослідження проводили на базі Комунального підприємства Луцька міська клінічна лікарня. Ви- бірка досліджуваних склала 40 осіб жіночої статі, віком 36-60 років, які проживали на території Волинської області. Згідно з сучасною віковою періодизацією за біологічними ознаками обстежувані належали до зрілого віку II-й період. За результатами обстеження та висновками лікаря жінкам було встановлено діагноз інфаркт міокарда (20 осіб) чи ішемічна хвороба серця (20 осіб).

Клінічні дослідження проводили 38.00 до 17.00 перед початком стаціонарного лікування в кардіологічному відділенні та перед випискою.

Дослідження показників периферійної крові здійснювали за допомогою гематологічного аналізатора ABX Micros 60. До початку роботи з гематологічним аналізатором здійснювали забір венозної крові.

Згідно з результатами клінічного аналізу крові в подальшому аналізували: гематокрит (Ht), швидкість осідання еритроцитів (ШОЕ), гемоглобін в крові (HB), кількість еритроцитів (RBC), тромбоцитів (PLT) та лейкоцитів (WBC), лейкоцитарну формулу, середню концентрацію гемоглобіну в еритроциті (МСНC), індекс розправлення еритроцита (RDW).

Статистичну обробку результатів проводили 3 використанням програми MS Excel 2019. Визначали нормальність розподілу даних. Для парного порівняння груп використовували достовірності Стьюдента (t) та Мана-Уїтні (W) і показник достовірності при порівнянні середніх величин (p). Різницю між двома середніми величинами вважали достовірною при значеннях $\mathrm{t} \geq 2,0$ i $\mathrm{p} \leq 0,05$. Визначали середнє значення показника (M), величину середньої похибки $( \pm \mathrm{m})[11]$.

\section{РЕЗУЛЬТАТИ ДОСЛІДЖЕННЯ}

Аналіз кількісних показників крові в жінок зрілого віку II-го періоду, які хворіють на ішемічну хворобу серця та інфаркт міокарда, показав, що кількість еритроцитів у досліджуваних груп була в межах норми. Так, у жінок, які хворіють на IXC, перед госпіталізацією показник RBC становив $4,6 \pm 0,05 \times 10^{12} /$ л, перед випискою $-4,6 \pm 0,15 \times 10^{12} /$ л. У пацієнток, які хворіють на IM, перед госпіталізацією кількість еритроцитів у крові становила $4,6 \pm 0,1 \times 10^{12} /$ л, а перед випискою дещо збільшилася $-4,8 \pm 0,1 \times 10^{12} /$ л.

Кількість гемоглобіну в жінок, які мають захворювання IXC, перед госпіталізацією становила $147 \pm 1,7$ г/л, а в осіб, яким був поставлений діагноз інфаркт міокарда, - 132 1 1,4 г/л. Перед випискою показники вмісту гемоглобіну в крові жінок обох дослідних груп практично не змінилися, порівняно зі значеннями перед госпіталізацією, та були в межах норми для даного віку. Проте в пацієнток із діагнозом IXC значення досліджуваного показника, порівняно із жінками, яким діагностовано інфаркт міокарда, були вищими.

Гематологічні дослідження показали, що об'ємна фракція еритроцитів у цільній крові (Ht) знаходилась у межах норми як перед госпіталізаці- 
єю, так і перед випискою зі стаціонарного лікування у жінок, яким поставлено діагноз ішемічна хвороба серця. Натомість у пацієнток із хворобою інфаркт міокарда перед випискою цей показник був нижчим за норму. У жінок із IXC показник Ht пе- ред госпіталізацією становив $41,7 \pm 0,4 \%$, перед

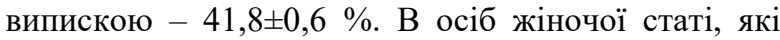
хворіють на IM, вищі значення спостерігали після

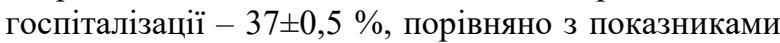
гематокриту перед випискою - $33 \pm 0,5$ \% (рис. 1.А).

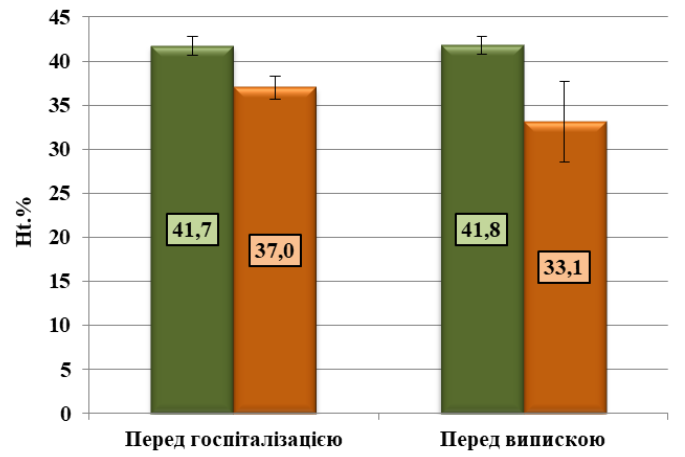

A

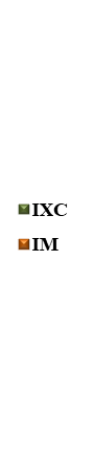

$\square I X C$
$\square I M$

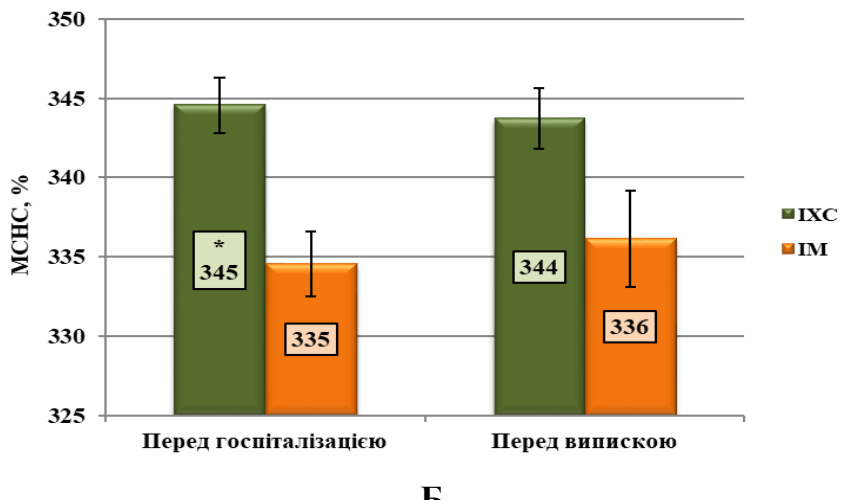

Б

Рис. 1. Значення гематокриту (А) та середньої концентрації гемоглобіну в еритроциті (Б) у жінок із діагнозом ішемічна хвороба серия (IXC) та інфаркт міокарда (IM) перед госпіталізацією та випискою зі стаціонарного лікування

* - статистично достовірно вище значення у жінок із діагнозом ішемічна хвороба серия, порівняно з пацієнтками з інфарктом міокарда, перед госпіталізаџією, $p \leq 0,05$

Показник середньої концентрації гемоглобіну в еритроциті характеризувався «нормою» в осіб жіночої статі незалежно від захворювання серця. Проте в пацієнток, які хворіють на IXC, значення досліджуваного показника були вищими порівняно iз значеннями осіб, які хворіють на IM (рис. 1.Б). Незалежно від періоду лікувального процесу у жінок із діагнозом інфаркт міокарда значення середньої концетрації гемоглобіну в еритроциті були нижчими порівняно із клінічними аналізами цього показника у пацієнток з ішемічною хворобою серця. У жінок із діагнозом ішемічна хвороба серця, порівняно $з$ пацієнтками з інфарктом міокарда, перед госпіталізацією виявлено достовірно вищі значення середньої концентрації гемоглобіну в еритроциті $(\mathrm{p} \leq 0,05)$.

Аналіз показника RDW виявив вищі значення як перед госпіталізацією, так і перед випискою зі стаціонарного лікування у жінок, яким поставлено діагноз інфаркт міокарда (перед госпіталізацією $14,3 \pm 0,2 \%$, перед випискою - 14,7 $\pm 0,1 \%$ ). У жінок iз IXC показник RDW перед госпіталізацією становив $12,6 \pm 0,1 \%$, перед випискою - 12,8 $80,6 \%$ (рис. 2.А). Варто зазначити, що незалежно від періоду лікувального процесу у жінок із діагнозом ішемічна хвороба серця значення індексу розправлення еритроцита були нижчими порівняно із клінічними значеннями цього показника у пацієнток із інфарктом міокарда. У жінок із діагнозом інфаркт міокарда, порівняно із пацієнтками з ішемічною хворобою серця, як перед госпіталізацією, так і перед випискою виявлено достовірно вищі значення індексу розправлення еритроцита $(\mathrm{p} \leq 0,05)$.

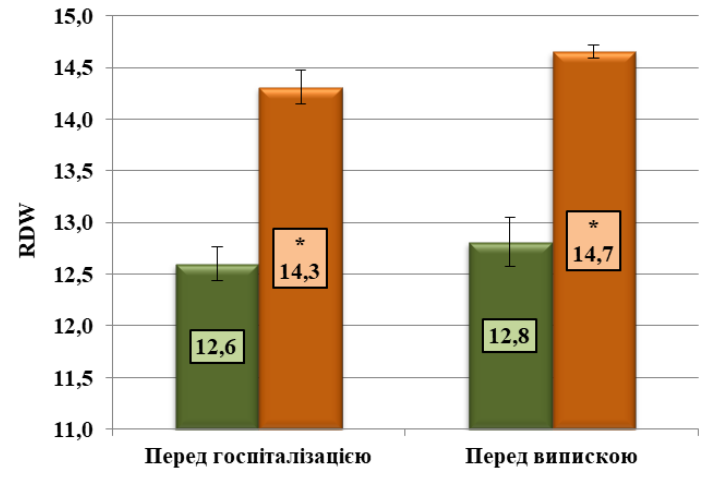

A

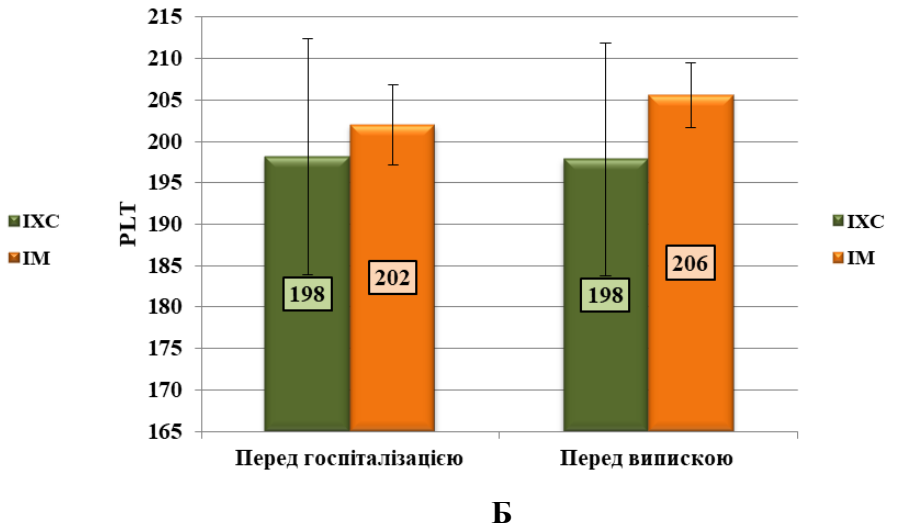

Рис. 2. Індекс розправлення еритрочита (А) та значення кількості тромбоцитів (Б) у жінок із діагнозом ішемічна хвороба серия (IXC) та інфаркт міокарда (IM) перед госпіталізацією та випискою зі стаиіонарного лікування;

* - статистично достовірно вище значення у жінок із діагнозом інфаркт міокарда, порівняно з пацієнтками з ішемічною хворобою серия, $p \leq 0,05$. 
Вміст тромбоцитів у крові жінок, які мають захворювання IXC, перед госпіталізацією становив $198,1 \pm 10 \times 10^{9} /$ л, а в осіб, яким був поставлений діагноз інфаркт міокарда, - 202 $\pm 10 \times 10^{9} /$ л. Перед випискою показники вмісту тромбоцитів у крові в жінок обох дослідних груп практично не змінилися порівняно зі значеннями перед госпіталізацією та були в межах норми для даного віку. Проте в пацієнток із діагнозом IM значення досліджуваного показника, порівняно із жінками, яким діагностовано ішемічну хворобу серця, були вищими (рис. 2.Б).

Значення ШОЕ у жінок із IXC перед госпіталізацією становило 10,4 $\pm 1,1$ мм/год, перед випискою - 10,3 $\pm 1,4$ мм/год. В осіб жіночої статі, які хворіють на IM, вищі значення спостерігали після госпі-
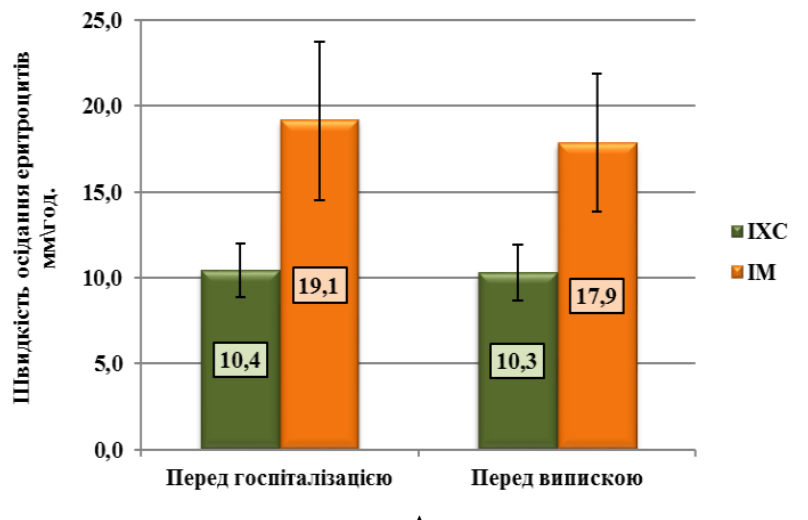

A талізації - 19,1士1,9 мм/год, порівняно з показниками перед випискою - 17,9 $\pm 1,6$ мм/год (рис. 3.А). Аналіз отриманих результатів засвідчив, що значення ШОЕ знаходилось у межах норми у жінок, що мають захворювання IXC. Натомість досліджувані жінки із діагнозом IM мали вищі за норму значення.

Кількість лейкоцитів у жінок зрілого віку, які мають захворювання IXC, як перед госпіталізацією, так і перед випискою становила $6,0 \pm 0,3 \times 10^{9} /$ л. В осіб, які мають захворювання IM, вищі значення показника WBC зафіксовано перед госпіталізацією $7,6 \pm 10 \times 10^{9} /$ л, порівняно із показниками перед випискою (рис. 3.Б).

Рис. 3. Швидкість осідання еритроцитів (А) та кількість лейкоцитів (Б) у крові в жінок із діагнозом ішемічна хвороба серия (IXC) та інфаркт міокарда (IM) перед госпіталізаиією й випискою зі стачіонарного лікування

Показник Lymph у жінок, що мають захворювання IXC, перед госпіталізацією становив $33,5 \pm 1,3$, перед випискою - 34,1 $\pm 1,3$. В осіб жіночої статі, що мають IM, вищі значення зафіксовано

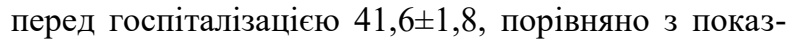
ником перед випискою. Варто зазначити, що неза-

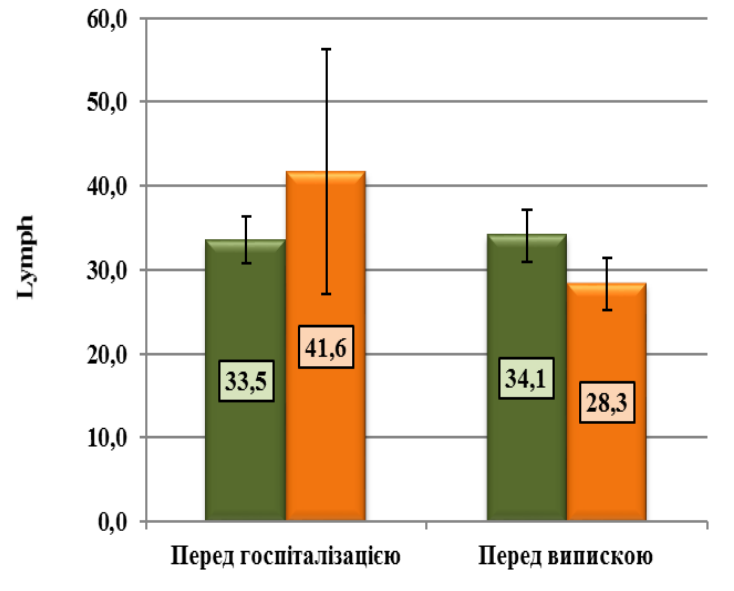

A

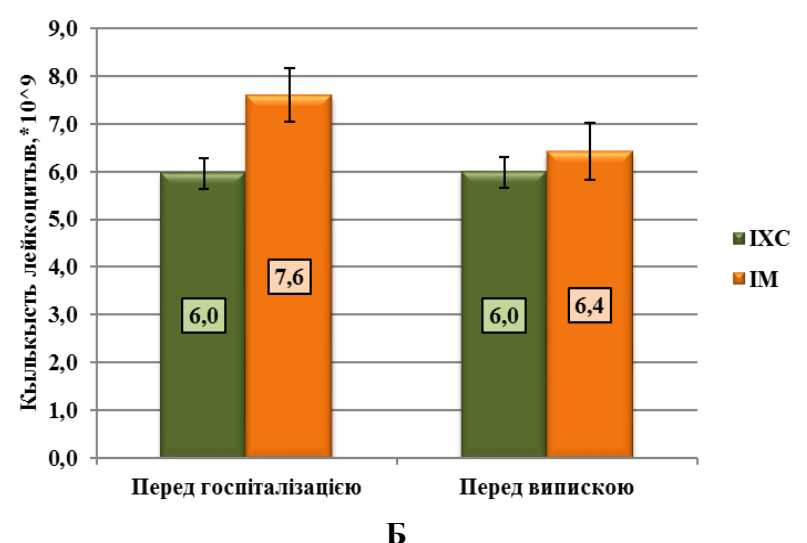

Б лежно від періоду лікувального процесу у жінок із діагнозом інфаркт міокарда перед госпіталізацією значення показника кількості лімфоцитів були вищими порівняно із клінічними аналізами кількості лейкоцитів у крові пацієнток із ішемічною хворобою серця (рис. 4.A).

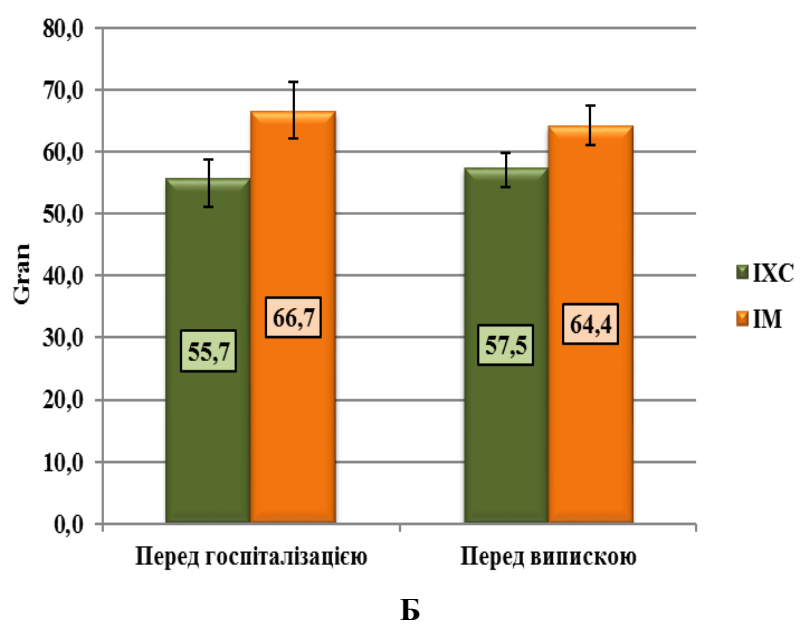

Рис. 4. Показник лімфоцитів (А) та гранулоцитів (Б) ужінок із діагнозом імемічна хвороба серия (IXC) та інфаркт міокарда (IM) перед госпіталізацією та випискою зі стаціонарного лікування

Кількість гранулоцитів у жінок, які мають захворювання IXC, перед госпіталізацією становила $55,7 \pm 0,5$, перед випискою - 57,5 $\pm 1,1$. В осіб жіночої статі з діагнозом IM спостерігалася подібна динаміка, вищі значення перед госпіталізацією $66,7 \pm 0,6$, порівняно із показниками перед випис- 
кою. Незалежно від періоду лікувального процесу у жінок із діагнозом інфаркт міокарда кількість сегментоядерних клітин крові були вищими порівняно із клінічними аналізами цього показника у пацієнток із ішемічною хворобою серця (рис. 4.Б).

Отже, за результатами клінічних аналізів крові перед госпіталізацією та випискою зі стаціонарного лікування виявлено, що досліджувані із хворобою інфаркт міокарда мали гірші значення, порівняно із показниками в осіб із діагнозом ішемічна хвороба серця, та значення вікової норми. Проте пацієнти 3 інфарктом міокарда більш реактивно реагували на медикаментозне лікування, що відображається в більш виразних змінах клінічного аналізу крові, порівняно з особами 3 діагнозом ішемічна хвороба серця.

\section{ОБГОВОРЕННЯ}

Важливим аспектом інфаркту міокарда $є$ його ускладнення як вияв ішемічної (коронарної) хвороби серця, що є наслідком зменшення його перфузії кров'ю і недостатньої доставки кисню, які поєднуються 3 порушенням відтоку продуктів обміну речовин. Виникнення ішемії міокарда може зумовлюватись: наявністю стенозу коронарної артерії; зміною тонусу або появою спазму артерії [12, 13]. Зміни, що відбуваються в організмі досліджуваних осіб жіночої статі зрілого віку, що хворіють на IM, виявляються у порушенні системи циркуляції крові, іiі транспортуванні до клітин і тканин організму, що в результаті призводить до змін у морфології та функціонуванні кровоносних судин, клітин і тканин. На системному рівні ці впливи відображаються у погіршенні функціонування серцево-судинної системи, іiі адаптаційних і резервних можливостей $[14,15]$. Результати нашого дослідження показують, що жінки, які мають діагноз інфаркт міокарда, 3 урахуванням зазначених змін, мають достовірні відхилення клінічних показників крові від норми, порівняно 3 пацієнтками 3 ішемічною хворобою серця. Виявлена особливість може сповільнювати процес одужання цих пацієнток та, ймовірно, використовувати в тактиці лікування додаткові медикаментозні препарати для стабілізації функціонального стану організму.

Зміни в клітинах крові хворих на інфаркт міокарда є більш виразні, що без лікувальної терапії та дотримання правил у харчуванні і способі життя може призвести до погіршення функціонування системи кровообігу та активації незворотності процесів в організмі.

\section{ВИСНОВКИ}

1. Аналіз кількісних та якісних показників системи крові у жінок зрілого віку, що мають захво- рювання серця, засвідчив, що найбільш чутливими до дії захворювання були показники крові: кількість еритроцитів, тромбоцитів, гемоглобіну, значення гематокриту та швидкості осідання еритроцитів, індекс розправлення еритроцита, а серед параметрів лейкоцитарної формули - нейтрофіли.

2. За результатами клінічних аналізів крові перед госпіталізацією та випискою зі стаціонарного лікування виявлено, що досліджувані із хворобою інфаркт міокарда мають гірші стосовно «норми» значення, порівняно з пацієнтками із діагнозом ішемічна хвороба серця.

\section{ЛIТЕРАТУРА}

1. Алмазов, В. А.; Беркович, О. О.; Ситніков, М. Ю. Ішемічна хвороба серця. Ендотеліальна дисфункція у хворих 3 дебютом ішемічної хвороби серця у різному віці. Кардіологія; 2001, № 3, c 20-24.

2. Амосова, К. М.; Захарова, В. І.; Ткачук, Л. С. Мікросудинна стенокардія: фактори ризику, особливості клінічного перебігу, коронарний резерв, функція ендотелію і вміст кальцію у вінцевих артеріях. Укр. кардіол. журнал; 2005, № 3 , c 46-51.

3. Динаміка показників стану здоров'я населення України за 1995-2005 роки: Аналітично-статистичний посібник / за ред. Д. К. Коваленко. Наука: Київ, 2006; 72 с.

4. Guideline for the Management of ST9 Elevation Myocardial Infarction. A Report of the American College of cardiology Foundation. American Heart Association Task Force on Practice Guidelines Circulation; 2013, Vol. 127, p 362-465.

5. Jollis, J. G.; Roettig, M. L.; Aluko, A. O. Implementation of a statewide system for coronary reperfusion for ST-segment elevation myocardial infarction. JAMA; 2007, № 20, p 2371 2380 .

6. Метельська, В. А.; Перова, Н. В. Сучасні основи діагностики та корекції атерогенних дисліпопротеідемій. Лікуючий лікар; 2002, Серпень, № 7-8, с 40-44.

7. Байес де Луна, А.; Фиол-Сала, М.; Антман, Э. М. ЭКГ при инфаркте миокарда с подъемом ST: пер. с англ. Мед. лит.: Москва, 2009, 112 c.

8. Alpert, J. Myocardial Infarction Redefined. J. Am. Coll. Cardiology; 2000, Vol. 36, p 959-969.

9. Бугаенко, В.В. Течение и исход ишемической болезни сердца у пациентов с болевой и безболевой ишемией миокарда. Міжнар. эндокринол. журнал; 2003, № 3, с 49-52.

10. Насонов, Е. Л.; Панюкова, Є. В.; Александрова, Є. М. С-реактивний білок маркер при атеросклерозі (нові дані). Бук. мед. вісник. Кардіологія; 2002, № 7, с 53-62.

11. Елисеева, И. И. Общая теория статистики. Университетская книга, Финансы и статистика: Москва; 2004, 656 с.

12. Рекомендації Європейського товариства кардіологів щодо ведення хворих, які підлягають некардіальній хірургії. Оцінка періопераційного кардіального ризику і кардіологічне лікування при несерцевій хірургії. Укр. кард. журнал; 2009 , № 5-6, с 6-25.

13. Boden, W. E.; O’Rourke, R. A.; Teo, K. K.; Hartigan, P. M.; Maron, D. J.; Kostuk, W. ; et. al. Optimal Medical Therapy with or without PCI for Stable Coronary Disease [Text]. New England Journal of Medicine; 2007, Vol. 356, Issue 15, p 1503 1516.

14. Комаров, Б. И.; Насонова, В. А.; Гогин, Е. Е.; и др. Болезни сердечно-сосудистой системы, ревматические болезни. Нева, ОЛМА-Пресс: Москва; 2003, 157 с.

15. Коркушко, О. В.; Лишневская, В. Ю. Микрососудистая ишемия миокарда - современный взгляд на проблему. Бук. мед. вісник; 2004, № 1, с 43-45. 